\title{
Current conservation status of Ratites
}

\section{J. Sales}

University of South Bohemia in Ceske Budejovice, Research Institute of Fish Culture and Hydrobiology, Zatisi 728, 38925 Vodnany, Czech Republic

Email: james_sales_1@ hotmail.com

\begin{abstract}
Living Ratites, which include several species or subspecies of ostriches, cassowaries, emus, rheas and kiwis, all with an important function in the ecosystem dynamics, endure the danger of extinction similarly to the extinct moas and elephant-birds. Whereas ostriches and emus, except for specific populations, are not seen as being endangered, cassowaries and kiwis are on the brink of extinction. Hunting by humans contributed most to the declining numbers in all families of Ratites. Some conservation management strategies have been developed for conservation of kiwis, one subspecies of cassowary, and some populations of ostriches, emus and rheas. These include captive breeding and release, habitat restoration, and public awareness. However, consideration of the limitations of the above techniques is often ignored.
\end{abstract}

Keywords: Cassowaries, Conservation, Emus, Kiwis, Ostriches, Rheas.

Date of online publication 26 January 2009 ISSN 0974-7907 (online) | 0974-7893 (print)

Editor: Fritz Huchzermeyer

Manuscript details:

Ms \# 01864

Received 29 September 2007

Final received 25 March 2008

Finally accepted 30 March 2008

Citation: Sales, J. (2009). Current conservation status of Ratites. Journal of Threatened Taxa 1(1): 09-16.

Copyright: ( ) J. Sales 2009. Creative Commons Attribution 3.0 Unported License. JoTT allows unrestricted use of this article in any medium for non-profit purposes, reproduction and distribution by providing adequate credit to the authors and the source of publication.

Author Details: James Sales received a PhD on the quality aspects of ostrich meat in 1994 at the University of Stellenbosch, South Africa. Thereafter he conducted research on nutrition, management and behaviour of farmed ostriches in South Africa, China, Australia, Malaysia, United Kingdom and Chile; emus in the USA, United Kingdom and Australia; and rheas in the United Kingdom, Chile and Argentina. He received a second $\mathrm{PhD}$ in aquaculture nutrition at Rhodes University, South Africa, in 2002, and is currently working in this topic at the Research Institute of Fish Culture and Hydrobiology in Vodnany, Czech Republic.

OPEN AGCESS | FREE DOWNLOAD

\section{INTRODUCTION}

Ratites include the ostrich of Africa, cassowary of Australasia, emu of Australia, rhea of South America and kiwi of New Zealand, as well as the recently extinct moa of New Zealand and elephant-bird of Madagascar (Cracraft 1974; Sibley \& Ahlquist 1990). The lack of a keel on the sternum in these species is associated with flightlessness. Phylogenetic analyses indicate that ostriches are basal, whereas South American rheas cluster with the Australasian emus, cassowaries and kiwis (Van Tuinen et al. 1998).

The significance of ratites in ecosystem dynamics cannot be ignored. The cassowary, an obligate frugivore, eats fruit from over 100 different species (Romer 1997), and plays a critical ecological role by dispersing seeds in the rainforest (Pratt 1982; Stocker \& Irvine 1983; Mack 1995; Wright 1998; Webber \& Woodrow 2004). Similarly, emus help to maintain the genetic mix in plant communities by distributing seeds (Rogers et al. 1993; McGrath \& Bass 1999), and they probably increase germination of seeds during passage through their digestive system (Noble 1975). Ratites also have longstanding relationships with humans, and have been a source of fascination since earliest times. However, human influence on declining ratite numbers is clearly illustrated in a model suggesting that hunting by man may have driven moas to extinction within a hundred years after Polynesian settlement in New Zealand in ca. AD 1300 (Holdaway \& Jacomb 2000).

In order to accentuate the importance of conservation of this order of birds, information regarding conservation of different ratite species has been reviewed and divided into species information, status, history of decline, and current conservation efforts for each family. It is hoped that this review will stimulate and guide interest in further research on conservation of ratite species.

\section{Ostriches}

Ostriches weigh between 93 and $130 \mathrm{~kg}$, and range between 1.7 and $2.7 \mathrm{~m}$ in height. They are native to the savannas of Africa, both north and south of the equatorial forest zone, and can live up to 75 years (Ostrich 2007). Clutch size of the ostrich in the wild varies between 5 and 36 eggs (Navarro \& Martella 2002), with the number of eggs hatched per total number of eggs laid reported as $65 \%$ for wild ostrich populations in Kenya (Bertram 1992).

Four living subspecies are recognised (Table 1). A fifth subspecies, Struthio camelus syriacus, called the Arabian ostrich, formerly common in the Arabian Peninsula, Syria and Iraq, was hunted to extinction circa 1966 (Ostrich 2007).

Ostriches are not listed as a threatened species by the World Conservation Union (IUCN) (Table 2). However, wild populations of $S$. c. camelus have been listed in Appendix I (species threatened with extinction that are or may be affected by trade) of CITES (Convention and International Trade in Endangered Species of Wild Fauna and Flora), and are protected by law throughout their range (Del Hoyo et al. 1992). Arabian ( $S$. $c$. syriacus) and West African (S. c. spatzi) ostriches are listed as endangered by the United 
Table 1. Taxonomy and distribution of ratites (De Mosenthal \& Harting 1879; Rothschild 1900; Howard \& Moore 1984; Del Hoyo et al. 1992; Romer 1997; Peterson 1999; Robertson 2003; IUCN 2007a; Ostrich 2007)

\begin{tabular}{|c|c|c|c|}
\hline Species & Subspecies & Named & Region \\
\hline Struthio camelus & $\begin{array}{l}\text { S. c. australis } \\
\text { S. c. camelus } \\
\text { S. c. molybdophanes } \\
\text { S. c. massaicus }\end{array}$ & $\begin{array}{l}\text { Gurney, } 1868 \\
\text { Linnaeus, } 1758 \\
\text { Reichenow, } 1883 \\
\text { Neumann, } 1898\end{array}$ & $\begin{array}{l}\text { Southern Africa } \\
\text { Ethiopia and East Sudan, Sahel, Senegal and West Mauritania } \\
\text { Somalia, Ethiopia, and northern Kenya } \\
\text { Kenya and Tanzania and parts of Southern Somalia }\end{array}$ \\
\hline Casuarius casuarius & $\begin{array}{l}\text { C. c. casuarius } \\
\text { C. c. aruensis } \\
\text { C. c. johnsoni } \\
\text { C. c. sclateri } \\
\text { C. c. bicarunculatus } \\
\text { C. c. tricarunculatus } \\
\text { C. c. bistriatus } \\
\text { C. c. iateralis }\end{array}$ & $\begin{array}{l}\text { Linnaeus, } 1758 \\
? \\
\text { Müller, } 1866 \\
\text { Salvadori, } 1881 \\
\text { Sclater, } 1860 ? \\
? \\
? \\
?\end{array}$ & $\begin{array}{l}\text { Ceram } \\
\text { Aru Islands } \\
\text { North Queensland } \\
\text { Southern New Guinea } \\
\text { Western Vogelkop } \\
\text { West Geelvink Bay } \\
\text { Geelvink Bay to Tana Mera } \\
?\end{array}$ \\
\hline C. unappendiculatus & $\begin{array}{l}\text { C. u. unappendiculatus } \\
\text { C. u. occipitalis } \\
\text { C. u. aurantiacus } \\
\text { C. u. philipi }\end{array}$ & $\begin{array}{l}\text { Blyth, } 1860 \\
\text { Salvadori, } 1878 ? \\
\text { Rothschild, } 1899 \\
\text { Rothschild, } 1898\end{array}$ & $\begin{array}{l}\text { Salawati and Western Vogelkop } \\
\text { Japen Island and nearby coast } \\
\text { Memberano to Sepik River } \\
\text { Sepik River to Astrolabe Bay }\end{array}$ \\
\hline C. bennetti & $\begin{array}{l}\text { C. b. benetti } \\
\text { C. b. papuanus } \\
\text { C. b. goodfellowi } \\
\text { C. b. claudii } \\
\text { C. b. picticollis } \\
\text { C. b. hecki } \\
\text { C. b. shawnmeyer }\end{array}$ & $\begin{array}{l}\text { Gould, } 1857 \\
\text { Schlegel } 1873 ? \\
? \\
? \\
\text { Sclater? } \\
\text { Rothschild, } 1899 \\
?\end{array}$ & $\begin{array}{l}\text { ? } \\
\text { Vogelkop } \\
\text { Japen Island } \\
\text { Nassau Mountains (Southern Slopes) } \\
\text { South-east New Guinea } \\
\text { Huon Peninsula to Sepik River } \\
\text { Kratke Mountains }\end{array}$ \\
\hline Dromaius novaehollandiae & $\begin{array}{l}\text { D. n. novaehollandiae } \\
\text { D. n. woodwardi } \\
\text { D. n. rothchildi }\end{array}$ & $\begin{array}{l}\text { Latham, } 1790 \\
\text { Mathews, } 1912 \\
\text { Mathews, } 1912\end{array}$ & $\begin{array}{l}\text { Central and South Queensland, Victoria and Southern Australia } \\
\text { Northwestern and Western Australia and the Northern Territory } \\
\text { Southwestern Australia }\end{array}$ \\
\hline Rhea americana & $\begin{array}{l}\text { R. a. americana } \\
\text { R. a. intermedia } \\
\text { R. a. nobilis } \\
\text { R. a. araneipes } \\
\text { R. a. albescens }\end{array}$ & $\begin{array}{l}\text { Linnaeus, } 1758 \\
\text { Rothschild \& Chubb, } 1914 \\
\text { Brodkorb, } 1939 \\
\text { Brodkorb, } 1938 \\
\text { Lynch \& Holmberg, } 1878\end{array}$ & $\begin{array}{l}\text { Northeastern to southeastern Brazil } \\
\text { Southeastern Brazil and Uruguay } \\
\text { Eastern Paraguay } \\
\text { Western Paraguay, eastern Bolivia, southwestern Brazil } \\
\text { North eastern and eastern Argentina }\end{array}$ \\
\hline Pterocnemia pennata & $\begin{array}{l}\text { P. p. pennata } \\
\text { P. p. garleppi } \\
\text { P. p. tarapacensis }\end{array}$ & $\begin{array}{l}\text { Orbigny, } 1834 \\
\text { Chubb, } 1913 \\
\text { Chubb, } 1913\end{array}$ & $\begin{array}{l}\text { Southern Chile, western, central and southern Argentina } \\
\text { Southern Peru, southwestern Bolivia northwestern Argentina } \\
\text { Northern Chile }\end{array}$ \\
\hline $\begin{array}{l}\text { Apteryx mantelli } \\
\text { A. australis } \\
\text { A. rowi } \\
\text { A. owenii } \\
\text { A. haastii }\end{array}$ & & $\begin{array}{l}\text { Bartlett, } 1852 \\
\text { Shaw, } 1813 \\
\text { Tennyson et al., } 2003 \\
\text { Gould, } 1847 \\
\text { Potts, } 1872\end{array}$ & $\begin{array}{l}\text { North Island } \\
\text { Near Haast, Stewart Island/Rakiura and Fiordland, South Island } \\
\text { Okarito, South Island } \\
\text { Kapiti Island and several smaller offshore islands } \\
\text { Northern South Island }\end{array}$ \\
\hline
\end{tabular}

States Fish \& Wildlife Service (2007). However, S. c. syriacus is extinct, as described above, whereas $S$. c. spatzi, once separated from $S$. c. camelus due to differences in eggshell pores, is no longer considered as valid (Ostrich 2007).

Ostriches were hunted since earliest times mainly for their feathers (Manlius 2001). At around 1859 it became evident that if buyers in Europe were to depend solely on feathers from wild birds hunted down in remote parts of Africa, birds would soon either become extinct, or they would be driven to parts where it would be extremely hard to get hold of them. This has led to the idea of farming of ostriches, which was promoted in Paris, and the first ostriches were domesticated in Algiers. Many farmers in the Cape Colony, South Africa, kept a number of tame ostriches on their farms as early as the 1870 s to supply plumes that were used in brooms. However, it seems that the first hatching of eggs from domesticated ostriches in South Africa occurred in the Beaufort and Oudtshoorn districts at about 1866 (De Mosenthal \& Harting 1879). Due to the increasing demand for feathers ostrich farming was booming in South Africa by 1910, when there were 746,736 breeding birds in the Cape Colony producing $336,854 \mathrm{~kg}$ of feathers annually (Holtzhausen \& Kotzé 1990). Importations to improve feather quality of the domesticated South African ostrich stocks involved the 1876,1888 and 1903 introductions of small numbers of "Barbary birds" from Tripoli, Algiers, Morocco and Tunisia, presumably S. c. camelus and the now extinct $S$. $c$. syriacus (Smit 1963; Freitag \& Robinson 1993). This was followed by the importation of 132 S. c. camelus from Nigeria in 1912 (Duerden 1919). Subsequently, the uncontrolled distribution of fertile hybrid ostriches throughout South Africa raised fears of widespread introgression, and thus loss of the genetic integrity of $S$. c. australis. However, whereas deep divisions in the mtDNA gene tree exist between representatives of the eastern $(S$. c. molybdophanes and $S$. c. massaicus) and northern African subspecies (S. c. camelus), little genetic diversity was evident among samples drawn from localities throughout southern Africa at the beginning of the 1990s. Obviously, these data reflect only mtDNA lineage survivorship in extant $S$. c. australis populations, and not on the possible degree of nuclear introgression (Freitag \& Robinson 1993). Furthermore, the expanding of the ostrich industry outside South Africa at the beginning of the 1990's for production of skins, meat and feathers has resulted in the intense uncontrolled crossing of S.c.massaicus, S. c. molybdophanes and $S$. c. australis in breeding programs, without any information on history of birds available (Sales 2006). 
Table 2. Conservation status of ratites

\begin{tabular}{lll}
\hline Species & Common name & IUCN (2007a) \\
\hline Struthio camelus & Ostrich & Least Concern \\
Casuarius casuarius & Southern Cassowary & Vulnerable \\
Casuarius unappendiculatus & Northern Cassowary & Vulnerable \\
Casuarius bennetti & Dwarf Cassowary & Near Threatened \\
Dromaius novaehollandiae & Emu & Least Concern \\
Rhea americana & Greater Rhea & Near Threatened \\
Pterocnemia pennata & Lesser Rhea & Near Threatened \\
Apteryx mantelli & Brown Kiwi & Endangered \\
Apteryx australis & Tokoeka & Vulnerable \\
Apteryx owenii & Little Spotted Kiwi & Vulnerable \\
Apteryx haastii & Great Spotted Kiwi & Vulnerable \\
\hline
\end{tabular}

Three projects have been identified that are currently holding S. c. camelus for eventual release in the wild. The Air Mountains of Northern Niger, a vast region of uplands, plateaux and broad, sandy valleys, harboured the most important remaining population of around 1500 birds of this subspecies up until the early 1990s. However, almost the entire population was destroyed by an armed rebellion in 1992 (Sahara Conservation Fund 2007). Entire flocks of ostriches in easily accessible wadis were shot by government military forces. They were used, according to ex-rebel sources, as a source of abdominal and bone marrow fat, which was sold to Algerian and Libyan dealers to be used as traditional rheumatism medicine. A survey in 2000 failed to detect any evidence of ostriches to the north and east of Iferouane, the main town of the northern Aïr (Ostrowski et al. 2001). In further extensive surveys in 2003-2004 no ostriches were seen throughout the Sahel of Mali, Niger and Burkino Faso (Thiollay 2006a). Despite the negative influence of overgrazing, woodland degradation and increasing disturbance on the survival of ostriches in these parts (Table 3 ), relentless hunting was likely to be the main reason for the dramatic decline (Thiollay 2006b). In 2006 a feasibility study was carried out to define a long-term captive breeding and reintroduction project in the Aïr region (Table 4). Simultaneously, captive ostriches elsewhere in Niger were inventoried for possible use to ultimately strengthen a breeding stock that was established in 1996 in Iférouane (Sahara Conservation Fund 2007).

A second project for protection of $S$. c. camelus is at the Hai Bar Yotvata Animal and Nature Reserve in the Arava valley in Israel. In May 200513 ostriches, raised with strict regulations and minimum human contact at this reserve, were released in the southern Negev plateau, each carrying a clear color tag and a transmitter (Kibbutz Lotan Center for Birdwatching 2005). Saudi Arabia's National Wildlife Research Center is also breeding North African ostriches for possible reintroduction into protected areas (National Commission for Wildlife Conservation and Development 2007).

\section{Cassowaries}

The family Casuariidae includes three species with a geographic distribution in New Guinea, the adjacent islands and northeastern Queensland (Table 1). Uncertainty about subspecies identification of this family could be attributed to the fact that a majority of the forms were described by Lord Rothschild from zoological garden specimens of unknown origin. Secondly, the great individual variation of these birds was not appreciated until recently (Mayer 1940).
Table 3. Causes of decline in numbers of ratites

\begin{tabular}{|c|c|c|}
\hline Species & Causes & References \\
\hline Ostriches & $\begin{array}{l}\text { Intensive hunting; Egg gathering; } \\
\text { Habitat destruction due to } \\
\text { livestock overgrazing }\end{array}$ & $\begin{array}{l}\text { Brown et al. (1982); Del } \\
\text { Hoyo et al. (1992); } \\
\text { Thiollay (2006b) }\end{array}$ \\
\hline Cassowary & $\begin{array}{l}\text { Habitat loss and fragmentation, } \\
\text { Traffic accidents; Visitor impacts; } \\
\text { Dogs; Competition and nest } \\
\text { predation by pigs; Disease; } \\
\text { Traditional unmanaged demand }\end{array}$ & $\begin{array}{l}\text { Crome \& Moore (1990); } \\
\text { Queensland Parks and } \\
\text { Wildlife Service (2001); } \\
\text { Johnson et al. (2004) }\end{array}$ \\
\hline Emu & $\begin{array}{l}\text { Habitat loss and fragmentation; } \\
\text { Deliberate slaughter; Collisions } \\
\text { with vehicles; Predation of eggs } \\
\text { and chicks by foxes, dogs and } \\
\text { feral pigs }\end{array}$ & $\begin{array}{l}\text { Department of } \\
\text { Environment and } \\
\text { Conservation (NSW) } \\
\text { (2007) }\end{array}$ \\
\hline Rhea & $\begin{array}{l}\text { Habitat loss, especially due to } \\
\text { sheep overgrazing; Egg gathering; } \\
\text { Predation by felids and feral dogs; } \\
\text { Illegal hunting by humans }\end{array}$ & Bucher and Nores (1988) \\
\hline Kiwi & Predation & $\begin{array}{l}\text { Taborsky (1988); } \\
\text { McLennan \& Potter (1992) }\end{array}$ \\
\hline
\end{tabular}

Studies on the biology of the cassowary are limited (Crome 1976). Clutches may vary from two to five eggs, with $80 \%$ of males breeding only once every 3 years (Moore 2007).

Research indicated that, if unmanaged, traditional demand for cassowaries in Papua New Guinea, which is exempt from State regulation, could lead to extirpation of populations. Traditional methods restricting the season of harvest, or the people who could eat or hunt cassowaries, seem to be not in place anymore (Johnson et al. 2004).

The southern cassowary, Casuarius casuarius johnsonii, the largest native vertebrate in the Australian rainforests (55-66 $\mathrm{kg}$ live weight), with numbers of fewer than 1500 (Kofron 1999), is classified as endangered under the Commonwealth Environment Protection and Biodiversity Conservation Act of 1999 (Queensland Parks and Wildlife Service 2001). However, fieldwork identified the need for the improvement of largescale survey techniques for cassowaries, and for caution in the application of this method and interpretation of its results (Westcott 1999). According to Moore (2007) the previous practice of surveying small areas has led to consistent overestimation of southern cassowary population densities, up to six times its real number, at Mission Beach, Queensland. Under the Queensland Nature Conservation Act of 1992 the Wet Tropics population, found from Mount Halifax/Paluma through to Cooktown, is listed as endangered, and the Cape York Peninsula population in the McIlwraith and Iron Ranges, Jardine River area and the Eastern Dunes as vulnerable. The Environmental Protection Agency/Queensland Parks and Wildlife Service, in partnership with other government organisations, research institutions, community groups and individuals, is working to protect and recover populations of southern cassowaries in Queensland (The State of Queensland, Environmental Protection Agency 2007). Although captive breeding is not seen as a priority, such actions may be useful in future when vacated areas are restored and reconnected (Queensland Parks and Wildlife Service 2001).

\section{Emus}

In the family Dromiceiidae a single extant species, Dromaius novaehollandiae, with three living subspecies (Table 1), is widely 
distributed throughout the Australian continent, although they avoid heavily populated areas, dense forest and arid areas (Davies 1963). The possibly distinct Tasmanian population, and two dwarf species, D. baudinianus on Kangaroo Island and $D$. ater on King Island, went extinct less than 200 years ago (Boles 2001). Emu females attain a weight of $55 \mathrm{~kg}$ and height of $1.8 \mathrm{~m}$, compared to $38 \mathrm{~kg}$ and $1.5 \mathrm{~m}$, respectively, for males (Fowler 1991). General biology and reproduction of emus, with a female laying on average 3.4 clutches of 6.7 eggs per clutch, spread over a period 83.8 days, has been reviewed by Sales (2007a).

Humans have been the emu's greatest predator since the Middle Upper Pleistocene (Boland 2003) in the inland of Australia (Kirk, 1981). Meat was used as food, and fat as a moisturizer and skin protector, as well as to heal burns and wounds and relieve muscle aches and pains (Fronteddu 2001). Emus have also been the targets of persecution by pastoralists, such as the infamous 'Emu Wars' staged in 1932 in Western Australia (Breckwoldt 1983). Already in the middle of the 1800's Bennett (1860) and Gould (1865) warned that unless attention was given to rearing and protecting of this bird it would become extinct.

Despite the loss of emus from heavily populated regions, emu numbers in Australia may have increased since European settlement. It is estimated that the emu population is 625,000 to 725,000 , with 100,000 to 200,000 in Western Australia, and the majority of the remaining populations in New South Wales and Queensland (Australian Museum 2001). However, some wild populations are at risk of local extinction due to small population sizes. The isolated eastern coastal emu population of the New South Wales north coast region and Port Stephens is listed as endangered by the New South Wales Government. Several priority actions (Table 4) have been identified by the Department of Environment and Conservation of New South Wales to help to recover the emu population in these regions (Department of Environment and Conservation (NSW) 2007). As a native species, the emu is protected in Western Australia under provisions of the Western Australian Wildlife Conservation Act of 1950 (Department of Conservation and Land Management (WA) 2007). However, state barrier fences, maintained by the Western Australian Department of Agriculture, were erected since the beginning of the 1900's between pastoral lands and wheatbelt properties to keep rabbits, emus and other agricultural pests out of the agricultural areas (Department of Agriculture and Food (WA) 2006). Also, emus were declared as a pest of agriculture under stipulations of the Western Australian Agriculture and Related Resources Protection Act of 1976. This declaration allows for the approval and implementation of a management program in various areas of the state. Although emus, due to different dietary preferences, do not compete with sheep for pasture, they can cause significant damage by feeding on grain crops. Emus can only be destroyed on private land after a damage license has been issued by the Western Australian Department of Conservation and Land Management, except where a restricted open season has been declared in the event of a buildup of birds along the barrier fences. With shooting the only legal method of destruction, poisoning is illegal for landholders under the Wildlife Conservation Act of 1950, but can be carried out by officers of the Western Australian Department of Agriculture after issue of appropriate damage licenses by the
Table 4. Suggestions for conservation of ratites

\begin{tabular}{|c|c|c|}
\hline Species & Suggestion & References \\
\hline Ostrich & $\begin{array}{l}\text { Captive breeding and release; } \\
\text { Genetic improvement; Public } \\
\text { awareness }\end{array}$ & $\begin{array}{l}\text { Sahara Conservation } \\
\text { Fund (2007) }\end{array}$ \\
\hline Cassowary & Habitat restoration & $\begin{array}{l}\text { Queensland Parks and } \\
\text { Wildlife Service (2001) }\end{array}$ \\
\hline Emu & $\begin{array}{l}\text { Habitat maintaining; Public } \\
\text { awareness; Predator control }\end{array}$ & $\begin{array}{l}\text { Department of Environment } \\
\text { and Conservation (NSW) (2007) }\end{array}$ \\
\hline Rhea & $\begin{array}{l}\text { Habitat maintaining; Control of } \\
\text { poaching; Captive breeding and } \\
\text { release }\end{array}$ & Bellis et al. (2004) \\
\hline Kiwi & $\begin{array}{l}\text { Predator control; Captive } \\
\text { breeding and release; } \\
\text { Establishment of 'kiwi } \\
\text { sanctuaries'; Public awareness }\end{array}$ & $\begin{array}{l}\text { Basse et al. (1999); Pierce } \\
\text { \& Westbrooke (2003); Grant } \\
\text { (2001); McLennan et al. (2004); } \\
\text { Kiwi Captive Management } \\
\text { Advisory Committee (2004); } \\
\text { Robertson (2004); James (2001) }\end{array}$ \\
\hline
\end{tabular}

Table 5. Population estimates of kiwis in New Zealand (Department of Conservation, New Zealand, 2007).

\begin{tabular}{ll}
\hline Kiwi & $\mathbf{2 0 0 6}$ \\
\hline North Island Brown (4 varieties) & 25000 \\
Okarito Brown & 250 \\
Haast Tokoeka & 300 \\
Southern Tokoeka (3 varieties) & 34500 \\
Little Spotted & 1425 \\
Great Spotted & 17000 \\
\hline
\end{tabular}

Department of Conservation and Land Management. Export of emu products is controlled by the Commonwealth Environmental Protection and Biodiversity Conservation Act of 1999, which requires that products must be from animals bred in captivity (Department of Conservation and Land Management (WA) 2007).

Despite an attempt in 1970 to farm emus in Western Australia for leather production, emus were only recognised in 1987 as an agricultural commodity in Australia. Since then emu farming has expanded to the USA, Europe, Asia and Africa (O’Malley 1995).

\section{Rheas}

Greater (Rhea americana) and Lesser (Pterocnema pennata) rheas, belonging to the family Rheidae, are native to the continent of South America. The several subspecies of both species (Table 1) have been hunted since pre-Hispanic times for meat, fat, eggs, feathers and skins (Adams 1908; Drenowatz et al. 1995). Adult Greater rheas have a height of 1.5 to $1.7 \mathrm{~m}$, and weight of around $25 \mathrm{~kg}$ (Del Hoyo et al. 1992). Although clutch sizes of 120 eggs have been reported for wild Greater rheas in Argentina, only 17 to $65 \%$ of eggs would hatch, with 26 to $50 \%$ of all chicks surviving until around 3 months of age (Navarro \& Martella 2002).

Despite legal protection in the last decades humans have become the main predator of rheas (Martella et al. 1995). Around 1870, 300,000 to 500,000 wild Greater rheas were killed in South America yearly for feather production (De Mosenthal \& Harting 1879). Free-ranging populations of rheas have declined drastically in South America, resulting in the inclusion of both species in Appendix I or II (species that are not presently threatened with extinction, but may become so if their trade is not regulated) of CITES. The Argentinean 
population of $P$. p. pennata was transferred from Appendix I to Appendix II in 2000, and it was proposed to do the same with the Chilean population, whose density (estimated 50,000 individuals) has increased from 1.29 individuals per $\mathrm{km}^{2}$ in 1976 to 5.13 per $\mathrm{km}^{2}$ in 2000 (IUCN 2007). The Andean Lesser rhea subspecies $P . p$. garleppi and $P$. p. tarapacensis are considered as endangered (Navarro et al. 2003). Although Lesser rheas, together with guanacos, have been classified as having a low risk of demographic extinction (Fernandez et al. 1997), this overlooks the potentially serious implications of the loss of their ecological roles in the ecosystem (Novaro et al. 2000).

Several studies, as summarised by Sales (2007b), have concentrated on describing the behaviour, reproduction, habitat and feeding habits of rheas, with subsequent suggestions for conservation (Table 4). Anti-predator training of Greater rheas was proved to be worthwhile for use in future reintroduction programs (de Azevedo \& Young 2006a,b,c).

Farming of Greater rheas has received attention in South America, North America and Europe since the 1990s (Navarro \& Martella 2002). However, it was only since 1994/95 that the Lesser rhea has been exploited as an animal with agricultural value in South America (Navarro et al. 2003). The fact that hybridization between the two species can occur in captivity (Delsuc et al. 2006; Sarasqueta 2006) points out that the differentiation between the two species is not complete. Species thus have to be strictly separated in private husbandries and zoos, with meaningful captive breeding programs followed to conserve the integrity of both species. This is especially important if the aim would be to release birds in the wild for reintroduction or population increase purposes (Delsuc et al. 2006).

\section{Kiwis}

According to genetic and biological differences, five species (Table 1) and six taxa of kiwis (Apteryx spp.) endemic to the three islands of New Zealand, and each endangered, are recognised by the New Zealand Department of Conservation (Sales 2005). A. rowi (Okarito Brown kiwis) and A. australis Haast (Haast Tokoekas) are classified as 'nationally critical', $A$. mantelli (North Island Brown kiwis) as 'seriously declining', $A$. haastii (Great Spotted kiwis) and A. australis (Southern Tokoekas) as 'gradually declining', and $A$. owenii (Little Spotted kiwis) as 'range restricted' (Hitchmough et al. 2005). Numbers for kiwis in New Zealand are presented in Table 5.

Kiwi females lay one to two eggs during a breeding season in the wild, with an incubation period of 65 to 85 days, depending on species. In captivity the number of eggs might increase to four to eight per breeding season (reviewed by Sales 2005).

More than a hundred years ago the extinction of kiwis, mainly due to severe hunting, was predicted (De Mosenthal \& Harting 1879; Buller 1905). A program of translocating kiwis and other species to offshore island reserves, undertaken by the New Zealand Department of Lands and Survey from the late 1890 s to about 1915 , failed after a series of setbacks, especially after the arrival of stoats (Colbourne 2005). Despite legal protection since 1896 and the setting aside of large tracts of pristine forests in parks and reserves, North Island Brown kiwi numbers were dropping by $5.8 \%$ each year (Robertson 2003). Only in 1991 significant coordinated conservation management action was taken to prevent kiwis from becoming extinct in New Zealand, with the launch of the Kiwi Recovery Program (Butler \& McLennan 1991; Robertson \& Colbourne 2003). In 1994 the Bank of New Zealand lodged the "Operation Nest Egg" program, which includes expertise and facilities from, among others, the Auckland Zoo, Rainbow Springs in Rotorua, the Whangarei Native Bird Rescue Centre, Napier's Westshore Wildlife Reserve, and Otorohanga Kiwi House, in partnership with the Department of Conservation (Bank of New Zealand Kiwi Recovery Trust 2002). The New Zealand's Department of Conservation's kiwi programs are matched by more than 60 community-led projects, aimed mainly at controlling of stoats and raising of kiwis in captivity for later release into the wild (Department of Conservation, New Zealand 2007).

It was found that predators killed at least $8 \%$ of chicks, $45 \%$ of juveniles, and possibly as many as $60 \%$ of all young kiwis (McLennan et al. 1996). Management comprises a variety of mainly experimental approaches (Table 4). Juvenile kiwis are raised in captivity to be returned to the wild upon reaching a size ( 800 to $1200 \mathrm{~g}$ ) when believed to be capable of resisting stoats (Grant 2001; Kiwi Captive Management Advisory Committee 2004; McLennan et al. 2004). Since 1994 about 700 birds have been hatched through the "Operation Nest Egg" program, and in the 2002/03 breeding season the program's first third-generation egg was laid (Bank of New Zealand Kiwi Recovery Trust 2002). According to Colbourne et al. (2005) concerns about captive-reared birds lacking social adjustment to life in the wild may be unfounded, based on behaviour and reproduction. Five areas, chosen to include significant populations of Okarito Brown kiwis and Haast Tokoekas, and sample populations of North Island Brown kiwis, were established as 'kiwi sanctuaries' in 2000 as part of the New Zealand Biodiversity Strategy (Robertson 2004). Kiwis are cryptic birds, and the most reliable monitoring regimes to evaluate the impact of conservation efforts include radio tracking, trained dogs (Robertson et al. 1999), and call count responses (Pierce \& Westbrooke 2003).

\section{Discussion and Conclusions}

The risk of immanent extinction exists for all living families of ratites. In order to identify the extent of the risk, priority should be given to identification of species and subspecies within families, followed by surveys of numbers. With this information available, threat classification systems set by conservation organizations for ratites, which are out of date and not a true reflection of the current situation, could be rectified. As stated by the Sahara Conservation Fund (2007), the most important factor in assuring success in the prevention of extinction of ratites will be the assurance that the causes for the original extinction have been addressed and remedied. However, since these causes are often irreversible, such as urban development, alternative solutions must be examined.

Captive breeding programs as practiced for ostriches and kiwis aim to produce substitutes for wild populations, supply demographic and genetic reservoirs, and serve as the last resort for species which have no immediate opportunity for survival in nature. The ultimate goal of such projects is to maintain options for re-establishment of natural populations (Conway 1980). Captive breeding programs are feasible in ratites with 
a high reproductive output, such as ostriches, emus and rheas, where survival of offspring could be dramatically improved through more effective management. However, captive breeding should never be seen as a substitute for in situ conservation of a species, to be beneficial to species conservation it has to be designed and applied as part of a science-based conservation management plan (World Wildlife Fund 2007). Careful consideration of limitations such as establishment of self-sufficient captive populations, success of re-introductions, high costs, domestication, preemption of other recovery techniques, disease outbreaks and maintenance of administrative continuity, have to be taken into account in such practices (Snyder et al. 1996).

Habitat loss is often blamed for decline in numbers for all ratite families. Habitat restoration means to restore the functional aspects of a place where one or more species are intended to live (Smallwood 2001). However, recommendations regarding habitat restoration in conservation plans for small or declining populations as a means of increasing carrying capacity and lowering extinction risk are often made without assessing how much, if at all, habitat restoration would benefit the population. The assumption that habitat loss has contributed to population declines, and that habitat restoration will be able to rescue declining populations, may not be the case when the populations are demographically limited rather than habitat limited (Schrott et al. 2005). Habitat restored with the right structural elements can still fail to sustain the species due to insufficient space and spatial contiguity with nearby habitat (Smallwood 2001). It is critical to evaluate habitat requirements for individual species, subspecies, or populations, and recommend strategies accordingly, and not to extrapolate from limited research with few experimental units.

Loss through domestication is rarely considered as a cause for wildlife extinction (Peterson et al. 2005). Domestication, as found with ostriches, emus and rheas, is a process whereby wild animals adapt to environments provided by humans, with genetic and behavioural changes occurring over generations (Price 1999). It has been suggested that domestication is a solution for wildlife extinction, because few if any animals domesticated as pets have gone extinct (Archer \& Pain 2000). However, this does not take into account that wildlife species might lose invaluable scientific, aesthetic, dialectical, and sacramental values through domestication (Rolston 1981).

Hybridization with or without introgression, commonly used to increase production of farm animals, has led to the extinction of many populations and species in plant and animal taxa (Rhymer \& Simberloff 1996). This tendency is also promoted in farmed ostriches (Brand et al. 2005) and farmed rheas (Sarasqueta 2005), and definitely is occurring in farmed emus. This has to be eliminated in conservation strategies for ratites, and great care has to be taken to prevent hybrids from farming operations being released into wild populations. Intentional hybridization would be appropriate when the population has lost substantial genetic variation through genetic drift and the detrimental effects of inbreeding depression are apparent (Allendorf et al. 2001).

Total extinction of several ratite families and populations has occurred in the recent past, in many cases due to human activity. Lessons learned from the past must be used to preserve the remaining members of this valuable and interesting order of birds.

\section{References}

Adams, S. (1908). Notes on the Rhea or South American ostrich. Condor 10: $69-71$.

Allendorf, F.W., R.F. Leary, P. Spruell \& J.K. Wenburg (2001). The problems with hybrids: setting conservation guidelines. Trends in Ecology \& Evolution 16: 613-622.

Archer, M. \& S. Pain (2000). Opinion interview: my pet possum. New Scientist 166: 40-43.

Australian Museum (2001). Fact sheets. Emu Dromaius novaehollandiae. http://www.amonline.net.au/birds/factsheets/emu.htm

Bank of New Zealand Kiwi Recovery Trust (2002). Bank of New Zealand save the kiwi. Operation Nest Egg. http://www.savethekiwi.org.nz/ BNZKiwiRecovery/OperationNestEgg/

Basse, B., J.A. McLennan \& G.C. Wake (1999). Analysis of the impact of stoats, Mustela erminea, on northern brown kiwi, Apteryx mantelli, in New Zealand. Wildlife Research 26: 227-237.

Bellis, L.M., M.B. Martella \& J.L. Navarro (2004). Habitat use by wild and captive-reared greater rheas Rhea americana in agricultural landscapes in Argentina. Oryx 38: 304-310.

Bennett, G. (1860). Gatherings of a Naturalist in Australasia: Being. Observations Principally on the Animal and Vegetable Productions of New South Wales, New Zealand and Some of the Austral Islands. John van Voorst, London, UK, 456pp.

Bertram, B.C.R. (1992). The Ostrich Communal Nesting System. Princeton University Press, Princeton, NJ, USA, 196pp.

Boland, C.R.J. (2003). An experimental test of the predator detection rates using groups of free-living emus. Ethology 109: 209-222.

Boles, W.E. (2001). A new emu (Dromaiinae) from the Late Oligocene Etadunna Formation. Emu 101: 317-321.

Brand, M.M., S.W.P. Cloete, L.C. Hoffman \& M. Muller (2005). A comparison of live weights, body measurements and reproductive traits in Zimbabwean Blue ostriches (Struthio camelus australis) and South African Black ostriches (S. camelus var. domesticus). Proceedings of the 3rd International Ratite Science Symposium \& XII World Ostrich Congress, Madrid, Spain, pp.73-80.

Breckwoldt, R. (1983). Wildlife in the Home Paddock: Nature Conservation for Australian Farmers. Angus \& Robertson, Sydney, Australia, 348pp.

Brown, L.H., E.K. Urban \& K. Newman (1982). The Birds of Africa, Vol. 1. Academic Press, London, UK, $521 \mathrm{pp}$.

Bucher, E.H. \& M. Nores (1988). Present status of birds in steppes and savannes of northern and central Argentina, pp. 71-79. In: Goriup, P.D. (ed.) Ecoloy and Conservation of Grassland Birds. International Council for Bird Preservation (ICBP) Technical Publication No. 7, Cambridge, UK.

Buller, W.L. (1905). Supplement to the Birds of New Zealand, Vol. 1. London, UK, 200pp.

Butler, D. \& J. McLennan (1991). Kiwi Recovery Plan. Threatened Species Recovery Plan 2. Department of Conservation, Wellington, New Zealand, 26pp.

Colbourne, R. (2005). Kiwi (Apteryx spp.) on offshore New Zealand Islands: Populations, Translocations and Identification of Potential Release Sites. Department of Conservation Research \& Development Series 208. Department of Conservation, Wellington, New Zealand, 24pp.

Colbourne, R., S. Bassett, T. Billing, H. McCormick, J. McLennan, A. Nelson \& H. Robertson (2005). The Development of Operation Nest Egg as a Tool in the Conservation Management of Kiwi. Science for conservation: 259, Department of Conservation, Wellington, New Zealand, 24pp.

Conway, W.G. (1980). An overview of captive propagation, pp.199208. In: Soulé, M.E. \& B.A. Wilcox (eds.) Conservation Biology: An Evolutionary-Ecological Perspective, B.A. Sinauer Associates, Inc. Publishers, Massachusetts, USA.

Cracraft, J. (1974). Phylogeny and evolution of the ratite birds. Ibis 116: 494-521.

Crome, F.H.J. (1976). Some observations on the biology of the cassowary in northern Queensland. Emu 76: 8-14.

Crome, F.H.J. \& L.A. Moore (1990). Cassowaries in north-eastern Queensland: Report of asurvey and a review and assessment of their status and conservation management needs. Australian Wildlife Research 17: $369-385$

Davies, S.J.J.F. (1963). Emus. Australian Natural History 14: 225-229. 
de Azevedo, C.S. \& R.J. Young (2006a). Behavioural responses of captive-born greater rheas Rhea americana Linnaeus (Rheiformes, Rheidae) submitted to antipredator training. Revista Brasileira de Zoologia 23: 186-193.

de Azevedo, C.S. \& R.J. Young (2006b). Do captive-born greater rheas Rhea americana Linnaeus (Rheiformes, Rheidae) remember antipredator training? Revista Brasileira de Zoologia 23: 194-201.

de Azevedo, C.S. \& R.J. Young (2006c). Shyness and boldness in greater rheas Rhea americana Linnaeus (Rheiformes, Rheidae): the effects of antipredator training on the personality of the birds. Revista Brasileira de Zoologia 23: 202-210.

Del Hoyo, J., A. Elliot \& J. Sargatal (1992). Handbook of the Birds of the World, Vol.1: Ostrich to Ducks. Lynx Edicions, Barcelona, Spain, 696pp.

Delsuc, F., M. Superina, G. Ferraris, M.-K. Tilak \& E.J.P. Douzery (2006). Molecular evidence for hybridisation between the two living species of South American ratites: potential conservation implications. Conservation Genetics 8: 503-507.

De Mosenthal, J. \& J.E. Harting (1879). Ostriches and Ostrich Farming, $2^{\text {nd }}$ Edition. Truebner \& Co., Ludgate Hill, London, UK, 246pp.

Department of Conservation, New Zealand (2007). Saving our kiwi: $A$ stocktake of kiwi conservation in New Zealand. http://www.doc.govt.nz/ upload/documents/conservation/native-animals/birds/saving-ourkiwi.pdf

Department of Conservation and Land Management (WA) (2007). Fauna Note No. 08/2005 Emu. Revised by Marion Massam and Tamra Chapman from text by Peter Mawson and John L. Long. http:// www.naturebase.net/pdf/plants_animals/living_with_wildlife/ 0805_emu.pdf

Department of Environment and Conservation (NSW) (2007). Emu population in the NSW North Coast Bioregion and Port Stephens LGA profile. http://threatenedspecies.environment.nsw.gov.au/tsprofile/ profile.aspx? id $=10250$

Department of Agriculture and Food (WA) (2006). The State Barrier Fence of Western Australia Centenary 1901-2001. http:// www.agric.wa.gov.au/pls/portal30/docs/FOLDER/IKMP/PW/ VP/BARRIER_INDEX.HTM

Drenowatz, C., J. Sales, D.V. Sarasqueta \& A. Weilbrenner (1995). History \& Geography, pp.3-29. In: Drenowatz, C. (ed.) Ratite Encyclopedia, Ratite Records Inc., San Antonio, Texas, USA.

Duerden, J.E. (1919). Crossing the North and South African Ostrich. Journal of Genetics 8: 156-198.

Fowler, M.E. (1991). Comparative clinical anatomy of ratites. Journal of Zoo and Wildlife Medicine 22: 204-227.

Freitag, S. \& T.J. Robinson (1993). Phylogeographic patterns in mitochondrial DNA of the ostrich (Struthio camelus). Auk 110: 614622 .

Fronteddu, M. (2001). Emu Oil and Other Emu Products. University of British Columbia Avian Research Centre Resource Document No. A002. Faculty of Agricultural Sciences, University of British Columbia, Canada, 30pp.

García Fernandez, J., R.A. Ojeda, R.M. Fraga, G.B. Díaz \& R.J. Baigún (1997). Libro rojo de mamíferos y aves amenazados de la Argentina. Fundación para la Conservación de las Especies y el Medio Ambiente, Buenos Aires, $221 \mathrm{pp}$

Gould, J. (1865). Handbook to the Birds of Australia, Vol. 2. London, UK, $630 \mathrm{pp}$

Grant, A. (2001). DNA Sexing of Brown Kiwi (Apteryx mantelli) from Feather Samples. DOC Science Internal Series 13, Department of Conservation, Wellington, New Zealand, 16pp.

Hitchmough, R., L. Bull \& P. Cromarty (2005). New Zealand threat classification system list. Science \& Technical Publishing, Department of Conservation, Wellington, New Zealand, 194pp.

Holdaway. R.N. \& C. Jacomb (2000). Rapid extinction of the moas (Aves: Dinornithiformes): model, test and implications. Science 287: 2250-2254

Holtzhausen, A. \& M. Kotzé (1990). The Ostrich. C.P. Nel Museum, Oudtshoorn, South Africa, $57 \mathrm{pp}$.

Howard, R. \& A. Moore (1991). A Complete Checklist of the Birds of the World, $2^{\text {nd }}$ Edition. Academic Press, Sydney, Australia, 622pp.

IUCN (2007a). 2006 IUCN Red List of Threatened Species. http// www.iucnredlist.org

IUCN (2007b). Transfer of the Chilean population of Rhea pennata pennata from Appendix I to Appendix II. Proponent: Chile. http:// intranet.iucn.org/webfiles/doc/SSC/CoP12/Analyses/1215.pdf

James, B. (2001). Evaluation of Kiwi Advocacy Programmes in Northland and Coromandel. Science for conservation: 161, Department of Conservation, Wellington, New Zealand, $51 \mathrm{pp}$.

Johnson, A., R. Bino \& P. Igag (2004). A preliminary evaluation of the sustainability of cassowary (Aves: Casauriidae) capture and trade in Papua New Guinea. Animal Conservation 7: 129-137.

Kibbutz Lotan Center for Birdwatching (2005). History in the making in southern Israel - Reintroduction of Ostriches into the wild. http:// www.birdingisrael.com/birdNews/special_reports/ostriches.htm

Kirk, R.L. (1981). Aboriginal Man Adapting: The Human Biology of Australian Aborigines. Clarendon Press, Oxford, UK, 242pp.

Kiwi Captive Management Advisory Committee (2004). Captive management plan for kiwi: Apteryx mantelli, Apteryx rowi, Apteryx australis, Apteryx australis 'Haast', Apteryx haastii, Apteryx owenii. Threatened Species Occasional Publication 24. Department of Conservation, Wellington, New Zealand, 42pp.

Kofron, C.P. (1999). Attacks to humans and domestic animals by the southern cassowary (Casuarius casuarius johnsonii) in Queensland, Australia. Journal of Zoology 249: 375-381.

Mack, A.L. (1995). Seed Dispersal by the Dwarf Cassowary, Casuarius bennetti, in Papua New Guinea. Ph.D. Thesis, University of Miami, Florida, USA, $106 \mathrm{pp}$.

Manlius, N. (2001). The ostrich in Egypt: past and present. Journal of Biogeography 28: 945-953.

Martella, M.B., D. Renison \& J.L. Navarro (1995). Vigilance in the Greater Rhea: Effects of vegetation height and group size. Journal of Field Ornithology 66: 215-220.

Mayer, E. (1940). Birds collected during the Whitney South Sea expedition. XLI. Notes on New Guinea birds. VI. American Museum Novitates 1056: 1-12.

McGrath, R.J. \& D. Bass (1999). Seed dispersal by emus on the New South Wales north-east coast. Emu 99: 248-252.

McLennan, J.A. \& M.A. Potter (1992). Distibution, population changes and management of brown kiwi in Hawke's Bay. New Zealand Journal of Ecology 16: 91-102.

McLennan, J.A., L. Dew, J. Miles, N. Gillingham \& R. Waiwai (2004). Size matters: predation risk and juvenile growth in North Island brown kiwi (Apteryx mantelli). New Zealand Journal of Ecology 28: 241-250

McLennan, J.A., M.A. Potter, H.A. Robertson, G.C. Wake, R. Colbourne, L. Dew, L. Joyce, A.J. McCann, J. Miles, P.J. Miller \& J. Reid (1996). Role of predation in the decline of kiwi, Apteryx spp., in New Zealand. New Zealand Journal of Ecology 20: 27-35.

Moore, L.A. (2007). Population ecology of the southern cassowary Casuarius casuarius johnsonii, Mission Beach north Queensland. Journal fuir Ornithologie 148: 357-366.

National Commission for Wildlife Conservation and Development (2007). National Wildlife Research Center (NWCR). http:// www.ncwcd.gov.sa/English/researchcenter.htm

Navarro, J.L. \& M.B. Martella (2002). Reproductivity and raising of Greater Rhea (Rhea americana) and Lesser Rhea (Pterocnemia pennata) - a review. Archiv fiur Geflïgellunde 66: 124-132.

Navarro, J.L., F.R. Barri, D.M. Maestri, D.O. Labuckas \& M.B. Martella (2003). Physical characteristics and chemical composition of Lesser Rhea (Pterocnemia pennata) eggs from farmed populations. British Poultry Science 44: 586-590.

Noble, J.C. (1975). The effects of emus (Dromaius novaehollandiae Latham) on the distribution of the Nitre bush (Nitraria billardieri DC). Journal of Ecology 63: 979-984.

Novaro, A.J., M.C. Funes \& R.S. Walker (2000). Ecological extinction of native prey of a carnivore assemblage in Argentine Patagonia. Biological Conservation 92: 25-33.

O'Malley, P.J. (1995). Nutrition of ratites: Comparison of emu and ostrich requirements, pp.53-61. In: Rowe, J.B. \& J.V. Nolan (eds.) Recent Advances in Animal Nutrition in Australia, University of New England, Armidale, Australia.

Ostrich, (2007). Wikipedia, The Free Encyclopedia. http:// en.wikipedia.org/w/index.php?title=Ostrich\&oldid $=119549229$

Ostrowski, S., M.S. Massalatchi \& M. Mamane (2001). Evidence of a dramatic decline of the. Red-necked Ostrich, Struthio camelus in the 
Air and Ténéré National Nature Preserve, Niger. Oryx 35: 349-352.

Peterson, A.P. (1999). Zoological Nomenclature Resource (Zoonomen). http:/ /www.zoonomen.net

Peterson, M.N., R.R. Lopez, E.J. Laurent, P.A. Frank, N.J. Silvy \& J. Liu (2005). Wildlife loss through domestication: The case of endangered key deer. Conservation Biology 19: 939-944.

Pierce, R.J. \& I.M. Westbrooke (2003). Call count responses of North Island brown kiwi to dierent levels of predator control in Northland, New Zealand. Biological Conservation 109: 175-180.

Pratt, T.K. (1982). Diet of the dwarf cassowary Casaurius benetti picticollis at Wau, Papua New Guinea. Emu 82: 283-285.

Price, E.O. (1999). Behavioral development in animals undergoing domestication. Applied Animal Behaviour Science 65: 245-271.

Queensland Parks \& Wildlife Service (2001). Recovery Plan for the Southern Cassowary Casuarius casuarius johnsonii 2001-2005. Queensland Parks and Wildlife Service, Brisbane, Australia. 39pp.

Rhymer, J.M. \& D. Simberloff (1996). Extinction by hybridization and introgression. Annual Review of Ecology and Systematics 27: 83-109.

Robertson, H. (2004). Research and Monitoring Plan for the Kiwi Sanctuaries. Science for conservation: 241, Department of Conservation, Wellington, New Zealand, 24pp.

Robertson, H.A. (2003). Kiwi (Apteryx spp.) Recovery Plan 1996-2006. Threatened Species Recovery Plan 50. Department of Conservation, Wellington, New Zealand, 26pp.

Robertson, H. \& R. Colbourne (2003). Kiwi (Apteryx spp.) Best Practice Manual. Department of Conservation, Wellington, New Zealand, $135 \mathrm{pp}$.

Robertson, H.A., R.M. Colbourne, P.J. Graham, P.J., Miller \& R.J. Pierce (1999). Survival of brown kiwi (Apteryx mantelli) exposed to brodifacoum poison in Northland. New Zealand Journal of Ecology 23: 225-231.

Rogers, R.W., D. Butler \& J. Carnell (1993). Dispersal germinable seeds by emus in semi-arid Queensland. Emu 93: 132-134.

Rolston III, H. (1981). Values in nature. Environmental Ethics 3: 113128.

Romer, L. (1997). Cassowary Husbandry Manual. Results of a workshop held at Currumbin Sanctuary 1996, Currumbin Sanctuary Conservation Unit, Currumbin, Queensland, Australia, 34pp.

Rothschild, W. (1900). A monograph of the genus Casuarius. Transactions of the Zoological Society of London 15: 109-148.

Sahara Conservation Fund (2007). Saving the last wild Saharan ostrich. http://www.saharaconservation.org/web/scf_ostrich_niger.php

Sales, J. (2005). The endangered kiwi: a review. Folia Zoologica 54: 1-20.

Sales, J. (2006). Digestive physiology and nutrition of ratites. Avian and Poultry Biology Reviews 17: 41-55.

Sales, J. (2007a). The Emu (Dromaius novaehollandiae): a review of its biology and commercial products. Avian and Poultry Biology Reviews 18: $1-20$.

Sales, J. (2007b). The Rhea, a ratite native to South America. Avian and Poultry Biology Reviews 17: 105-124.

Sarasqueta, D.V. (2005). Aspects of rearing, reproduction and hybridization of Darwin's rhea or Choique (Rhea pennata syn, Pterocnemia pennata, $s p p$ pennata). Proceedings of the $3^{\text {rd }}$ International Ratite Science
Symposium \& XII World Ostrich Congress, Madrid, Spain, pp. 3544 .

Schrott, G.R., K.A. With \& A.W. King (2005). Demographic limitations of the ability of habitat restoration to rescue declining populations. Conservation Biology 19: 1181-1193.

Sibley, C.G. \& J.E. Ahlquist (1990). Phylogeny and classification of birds: a study in molecular evolution. Yale University Press, New Haven, USA, 1080 p.

Smallwood, K.S. (2001). Linking habitat restoration to meaningful units of animal demography. Restoration Ecology 9: 253-261.

Smit, D.J.v.Z. (1963). Ostrich farming in the Little Karoo. Bulletin No. 358. Department of Agricultural Technical Services, Heer Printing Co. Ltd., Pretoria, South Africa, 103pp.

Snyder, N.F.R., S.R. Derrickson, S.R. Beissinger, J.W. Wiley, T.B. Smith, W.D. Toone \& B. Miller (1996). Limitations of captive breeding in endangered species recovery. Conservation Biology 10: 338-348.

Stocker, G.C. \& A.K. Irvine (1983). Seed dispersal by cassowaries (Casaurius casaurius) in north Queensland's rainforests. Biotropica 15: $170-176$.

Taborsky, M. (1988). Kiwis and dog predation: Observations in Waitangi State Forest. Notornis 35: 197-202.

The State of Queensland, Environmental Protection Agency (2007). Cassowary. http://www.epa.qld.gov.au/nature_conservation/wildlife/ threatened_plants_and_animals/endangered/cassowary/

Thiollay, J.M. (2006a). The decline of raptors in West Africa: longterm assessment and the role of protected areas. Ibis 148: 240-254.

Thiollay, J.M. (2006b). Severe decline of large birds in the Northern Sahel of West Africa: a long-term assessment. Bird Conservation International 16: 1-13.

Van Tuinen, M., C.G. Sibley \& S.B. Hedges (1998). Phylogeny and biogeography of ratite birds inferred from DNA sequences of the mitochondrial ribosomal genes. Molecular Biology and Evolution 15: 370-376.

Webber, B.L. \& I.E. Woodrow (2004). Cassowary frugivory, seed defleshing and fruit fly infestation influence the transition from seed to seedling in the rare Australian rainforest tree, Ryparosa sp. nov. 1 (Achariaceae). Functional Plant Biology 31: 505-516.

Westcott, D.A. (1999). Counting cassowaries: what does cassowary sign reveal about their abundance? Wildlife Research 26: 61-67.

World Wildlife Fund (2007). Captive Breeding - WWF Policy Statement 2007 http://www.panda.org/news_facts/publications/index.cfm? uNewsID $=103860$

Wright, D.D. (1998). Fruit choice by the dwarf cassowary, Casuarius bennetti, over a three year period in Papua New Guinea. Ph.D. Thesis, University of Miami, Florida, USA, 193pp.

United States Fish \& Wildlife Service (2007). Species information threatened and endangered animals and plants. http://www.fws.gov/endangered/ wildlife.html. 